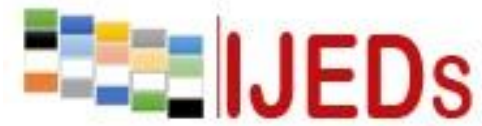

http://ijeds.ppj.unp.ac.id/index.php/IJEDS

\title{
THE INFLUENCEOF COOPERATIVE LEARNING MODEL GROUP INVESTIGATION (GI) TYPE AND LEARNING MOTIVATION APPROACH WITH THE UNDERSTANDING CONCEPTS AND SOLVING MATHEMATICAL PROBLEM ON GRADE 7 IN UPT SMP NEGERI AIRPURA
}

\author{
*Erna Butsila Wati ${ }^{1}$, Ahmad Fauzan ${ }^{2}$ \\ ${ }^{1}$ Graduate Program of Educational Technology, Universitas Negeri Padang, Indonesia \\ ${ }^{2}$ Lecture Of Mathematics Education Of Master Program, Universitas Negeri Padang, \\ Indonesia \\ Email: yonnaazza@yahoo.com
}

*Corresponding Author, Received: November 12, 2019, Revised: December 10, 2019, Accepted: December 21, 2019

\begin{abstract}
The aims from this study observe at the influenceof cooperative learning model group investigation (GI) type and learning motivation on students' ability to understand concepts and solve problems in Mathematics in UPT SMP Negeri Airpura both to the students who had high previous knowledge and those who had low previous knowledge.This was a quasi experimental research. Samples are choose using randomized sample. Data are analyzed using t-test, Mann Whitney test and two Ways Anova using MINITAB software. The result of data analysis showed that : (1) the influenceof cooperative learning model group investigation (GI) type and learning motivation can improve students' MGI skills and still need to improve their ability to understand concepts., (4) there was no interaction between learning approaches and previous knowledge toward the eighth grade students.
\end{abstract}

Keywords : Concept Understanding, Problem Solving

\section{INTRODUCTION}

Mathematics is the science wihich is the basis of the development of modern technology and the development of other scientific disciplines. Given the important role of mathematics, it is natural that mathematics as a compulsory subject, needs to be mastered and understood as well as possible by students in school. This is in accordance with the statement mathematics grows and develoGI for itself as a science, also to serve 


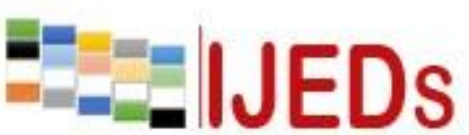

http://ijeds.ppj.unp.ac.id/index.php/IJEDS
International Journal of Educational Dynamics

Vol. 2 No. 1 (pp. 44-54) Desember 2019

p_ISSN 2655-4852

e_ISSN 2655-5093

the needs of science in its development and operation[1]. In addition, the development of the ability to think logically and appreciate the usefulness of students' mathematics is also the most important thing in the aim of learning mathematics. The existence of these thinking skills students will be accustomed to reasoning, expressing opinions and ideas, maintaining opinions, attracting conclusions, understanding concepts and solving mathematical problems so that any form of questions given by students will be able to answer them properly and correctly. Problem solving skills and conceptual understanding are the focus of research in developing students' mathematical ability goals.

Related to the importance of this GI ability [2] said In mathematics, GI is the most effective concept for the concept to contextualization and re-contextualization, to transfer basic mathematical and operational knowledge to ensure useful and continuous learning. Besides that [3] also said that "Mathematics education in Indonesia is aimed at understanding mathematical concepts and ideas which are then applied in routine and non-routine problem solving through the development, communication and connection of mathematics and in other fields ". To improve students' understanding of mathematical concepts, the mathematics learning process should be oriented towards mathematical daily experience, the teacher must connect the subject matter with the real world of students so that students are able to find concepts in accordance with student experience, because a lesson will be easier to understand and remember when students discover the concept of the lesson themselves. In line with that [4] also said that Learning mathematics is very important to involve students in solving problems problems related to the real student world.

Based on the results of interviews with teachers in the field of mathematics studies revealed that if there are still many students who get grades below the value of mastery learning, learning is still focusing on the teacher not on students. This is because students are lazy to study on their own, when discussions and presentations to the front of the class are more dominated by students who excel in their grouGI, when given training students who still copy the answers of their friends without trying to find their own answers. This happens because students are used to material without understanding it. This is in line with the statement of [4] that " the process of learning 


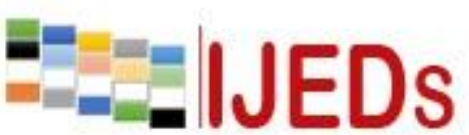

http://ijeds.ppj.unp.ac.id/index.php/IJEDS
International Journal of Educational Dynamics

Vol. 2 No. 1 (pp. 44-54) Desember 2019

p_ISSN 2655-4852

e_ISSN 2655-5093

mathematics in Indonesia is still mechanically centered on teachers and for the median it is practiced conventionally. While students only memorize facts, concepts and formulas. the process in the class does not provide an opportunity for students to build their own learning experiences making students passive and inactive students in the learning process

From the results obtained, it can be concluded that there needs to be an effort to improve students' mathematical abilities so that optimal learning outcomes are obtained. For this reason, it is necessary to diagnose the factors that determine the success of learning. One important factor that supports mathematical ability is the initial ability of students. The functioning of this initial ability can be seen in the learning process. One way that can be done is to use the influenceof co

\section{METHOD}

This type of research is research using quantitative in the form of experimental quasy. Consists of two classes, namely the research class and the testing class. the influenceof cooperative learning model group investigation (GI) type and learning motivation in the researh class and conventional in the testing class. The variables in this study consisted of a) the independent variable, the influenceof cooperative learning model group investigation (GI) type and learning motivation and conventional learning, b) the dependent variable, namely the mathematical ability which includes the ability to understand concepts and problem solving abilities, c) the moderator variable, namely student's motivation to study. The design of this study was Random Group Only Design

The population is students of class VII UPT SMPN Airpura. The sample consists of two classes, namely experiment and control. The sample selection is done randomly based on the value of the first semester of semester VII of the 2018/2019 school year. The data in this study are 2, namely primary data is student learning outcomes data in the research class and the testing class while secondary data is data about the number of students in class VII and data about the results of the 1st Semester Student Mathematics Examination. There are 3 stages in the implementation of this research, namely 1) Preparation , 2) Implementation and 3) Completion . at the final stage, the final test is carried out on two class group GI to find out the concept scores of students 'understanding abilities and scores of pstudents' problem solving. 


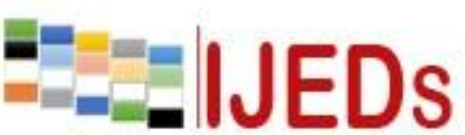

http://ijeds.ppj.unp.ac.id/index.php/IJEDS

\section{RESULTS AND DISCUSSION}

In quantitative research before conducting research in advance Data Analysis Techniques are performed. The aim is to test the hypothesis that has been formulated. The stepr - stepr in data analysis techniques are 1). Perform Data Normality test, to find out whether the sample comes from a population that is normally distributed or not. The normality test was carried out using the KS Test. 2) Perform Data Homogeneity Test to find out whether the data has a homogeneous variance or not. The test is carried out using Test F. 3) Test the Hypothesis. This test aims to find out whether the research hypothesis is rejected or accepted. Based on the Testing criteria if P-value $>0,05$, then $\mathrm{H}_{0}$ is accepted

\subsection{Data Understanding Text Concepts and Student Problem Solving}

Data about the students' concept understanding and problem solving tests were obtained through the final test. To see the difference in results from the two classes, an Independent Sample T-Test is performed, which is the average difference test. The results obtained in the following table

Table 1. Statistical Data Students UMC Tests

\begin{tabular}{l|l|l|l|l}
\hline \multirow{2}{*}{ Group } & \multicolumn{4}{l}{ Concept Understanding Ability } \\
\cline { 2 - 5 } & Xmin & Xmax & X & S \\
\hline Experiment & 0 & 21 & 17,05 & 3,99 \\
\hline Control & 0 & 21 & 16,4 & 5,04 \\
\hline
\end{tabular}

From the calculation results show that the average ability to UMC from the research class students is better than the class ability to understand the concept of the testing class means that the research class students have good conceptual comprehension skills than the testing class. The standard deviation of the experimental class is smaller than the control class, this means that understanding the concepts of students taught with conventional learning is more diverse than understanding students' mathematical concepts taught with the influenceof cooperative learning model group investigation (GI) type and learning motivation.

Table 2. Statistical Data Tests for Solving Students Mathematical Problems

\begin{tabular}{l|l|l|l|l}
\hline \multirow{2}{*}{ Group } & \multicolumn{4}{l}{ Problem solving } \\
\cline { 2 - 5 } & Xmin & Xmax & X & S \\
\hline Experiment & 0 & 33 & 23,1 & 6,17 \\
\hline Control & 0 & 27 & 12,94 & 7,885 \\
\hline
\end{tabular}




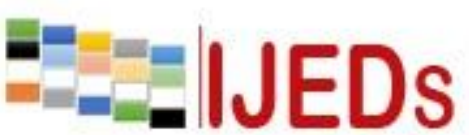

http://ijeds.ppj.unp.ac.id/index.php/IJEDS
International Journal of Educational Dynamics

Vol. 2 No. 1 (pp. 44-54) Desember 2019

p_ISSN 2655-4852

e_ISSN 2655-5093

From the calculation results show that the average mathematical GI ability of students the experimental class is higher from mathematical problem solving ability of the testing class, which means that the experimental class students have better problem solving skills from control class. The SD of the research class is smaller from testing class, this means that problem solving of students taught with conventional learning is more diverse than the MGI students taught with the the influenceof cooperative learning model group investigation (GI) type and learning motivation

In testing the normality of the test scores for understanding concepts and solving mathematical problems students performed the Kolmogorov-Smirnov (KS) test, the criteria were normal if $\mathrm{P}$-value $>0.05$.

Table 3. Normality Test Ability to Understanding Concepts and Solving Problems

\begin{tabular}{l|l|l|l|l}
\hline \multirow{2}{*}{ Value } & \multicolumn{3}{|l|}{ Experiment Class } & Control Class \\
\cline { 2 - 5 } & $\begin{array}{l}\text { Concept } \\
\text { Understanding }\end{array}$ & $\begin{array}{l}\text { Problem } \\
\text { Solving }\end{array}$ & $\begin{array}{l}\text { Concept } \\
\text { Understanding }\end{array}$ & $\begin{array}{l}\text { Problem } \\
\text { Solving }\end{array}$ \\
\hline P-value & 0,002 & 0,007 & 0,000 & 0,151 \\
\hline Information & Not Normal & Not Normal & Not Normal & Normal \\
\hline
\end{tabular}

From the test relusts that the value of UCM of the research class and the testing class are not normally distributed. Because data is not normally distributed, Homogeneity Test is not necessary. So that for hypothesis testing, Mann Whitney U test was performed using SGIS. The test criteria is if P-value $>0.05$ then Accept H0. Based on testing the significant value obtained is $=0.4505$ so that the P-value> 0.05 then accept H0. This means that the students' UMC of the research class is not higher than the understanding of the concept of the testing class.

As for the value of problem solving experimental and control classes are also not normally distributed because one of them is not normal then the homogeneity test is also not conducted. For the Hypothesis Test Mann Whitney U Test is used. The test criteria is if P-value> 0.05 then Accept $\mathrm{H}_{0}$. Based on testing the Significant value obtained is 0,000 which means $\mathrm{P}$-value $<0.05$ then Reject $\mathrm{H}_{0}$. This means that the ability to solve mathematical problems in the experimental class is higher than the ability to solve the control class.

\subsection{Concept Understanding Test Data and Problem Solving for Early High Student}




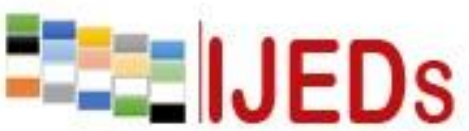

http://ijeds.ppj.unp.ac.id/index.php/IJEDS
International Journal of Educational Dynamics

Vol. 2 No. 1 (pp. 44-54) Desember 2019

p_ISSN 2655-4852

e_ISSN 2655-5093

Data about the concept understanding and problem solving tests of high-ability early students were obtained through the final tests given at the end of the study in both classes, namely the experimental class and the control class. To see the difference in the results of the two classes, the Independent Sample T-Test was conducted, namely the average difference test. From the student data obtained the maximum score, min score, average score and SD as in the following table.

Table 4. Statistical Data on Mathematical Understanding Tests for Early High Student

\begin{tabular}{l|l|l|l|l}
\hline \multirow{2}{*}{ Group } & \multicolumn{4}{|l}{ Concept Understanding Ability } \\
\cline { 2 - 5 } & Xmin & Xmax & X & S \\
\hline Experiment & 14 & 21 & 18,11 & 2,261 \\
\hline Control & 19 & 21 & 20,67 & 0,816 \\
\hline
\end{tabular}

Based on the table 4 it can be seen that the average conceptual comprehension ability of high-ability students in the control class is higher than the average ability to understand the experimental class concept. This means that the ability to understand the mathematical concepts of the researchl class is no better than the understanding of the testing class concepts. Based on the standard deviation value, the understanding of the mathematical concepts of students with high motivation to learn in the research class is more diverse than the control class.

Table 5. Statistical Data on Mathematical Problem Solving for Early High Students

\begin{tabular}{l|l|l|l|l}
\hline \multirow{2}{*}{ Gruop } & \multicolumn{4}{|l}{ Problem Solving Ability } \\
\cline { 2 - 5 } & Xmin & Xmax & X & S \\
\hline Exsperiment & 14 & 33 & 26,78 & 5,263 \\
\hline Control & 21 & 27 & 22,83 & 2,137 \\
\hline
\end{tabular}

Based on the table 5 it can be seen that the average MGI ability of the research class students is higher than the average mathematical GI ability of the testing class. This means that the MGI ability of research class students is better than the mathematics GI ability of the testing class students. Based on the SD value of MGI students with high motivation to learn in the research class are more diverse than the testing class. 


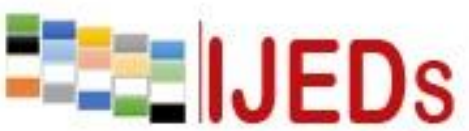

http://ijeds.ppj.unp.ac.id/index.php/IJEDS
International Journal of Educational Dynamics

Vol. 2 No. 1 (pp. 44-54) Desember 2019

p_ISSN 2655-4852

e_ISSN 2655-5093

Table 6. Data Normality Test Concept Understanding Tests and MGI High Early Ability Students in Experiment ang Control Class.

\begin{tabular}{l|l|l|l|l}
\hline \multirow{4}{*}{ Value } & \multicolumn{3}{l}{ Kemampuan Awal Tinggi } & \multicolumn{2}{l}{ Control Class } \\
\cline { 2 - 5 } & Experiment Class & $\begin{array}{l}\text { Problem } \\
\text { Solving }\end{array}$ & $\begin{array}{l}\text { Undesrstand } \\
\text { Concept }\end{array}$ & $\begin{array}{l}\text { Problem } \\
\text { Solving }\end{array}$ \\
\cline { 2 - 5 } & $\begin{array}{l}\text { Undesrstand } \\
\text { Concept }\end{array}$ & 0,000 & 0,000 & 0,057 \\
\hline P-value & 0,085 & Not Normal & Not Normal & Normal \\
\hline Information & Normal & \multicolumn{3}{l}{} \\
\hline
\end{tabular}

In testing the normality of the concept understanding test and MGI students with high initial ability of the research class and the testing class, the results of the experimental class understanding of the test results are normally distributed, while the understanding of the testing class concept test is not normal, so it is concluded that the data is not normally distributed so that the HT is used MWU. With the criterion if the P-value> 0.05 then Accept $\mathrm{H}_{0}$. Based on the test results obtained with a significant value $=0.005$. So that the $\mathrm{P}$-value $<0.05$ then Reject $\mathrm{H}_{0}$. This means that the UMC of high-ability early students in the research class is higher than the understanding of the mathematical concepts of high-ability students of high-grade control class.

Whereas for the normality test for solving the resrach class and the testing class there is one that is not normal, namely for the experimental class P-value $=0,000$ and the control class P-value $=0.057$, it can be concluded that the data is not normally distributed so for the Hypothesis Test Mann Test is used MWU With the test criterion if P-value> 0.05 then Accept $\mathrm{H}_{0}$. Based on testing obtained a significant value of 0.012, so Reject $\mathrm{H}_{0}$. This means that the mathematical problem solving of students with high initial ability of the resarch class is higher than the problem solving of mathematics of students with high initial ability of the control class.

\subsection{Concept Understanding and Problem Solving Test Data for Early Low Ability Student}

Data about the concept understanding and problem solving tests of students with low motivation to learn were obtained through the final test given at the end of the study in both classes, namely the research class and the testing class. To see the difference in the results of the two classes, the IST-Test was conducted, namely the average difference test. From the student data obtained the maximum score, minimum score, average score and standard deviation as in the following table: 


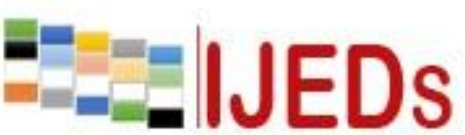

http://ijeds.ppj.unp.ac.id/index.php/IJEDS
International Journal of Educational Dynamics

Vol. 2 No. 1 (pp. 44-54) Desember 2019

p_ISSN 2655-4852

e_ISSN 2655-5093

Table 7. Sta Statistics Data Understanding Tests of Mathematics Concepts of Early Low Ability Students

\begin{tabular}{l|l|l|l|l}
\hline \multirow{2}{*}{ Group } & \multicolumn{4}{|l}{ Concept Understanding Ability } \\
\cline { 2 - 5 } & Xmin & Xmax & X & S \\
\hline Experiment & 12 & 21 & 17,40 & 3,362 \\
\hline Control & 0 & 21 & 12,89 & 6,936 \\
\hline
\end{tabular}

Based on the table 7 , the average ability of students with low motivation to learn to understand the research class is higher than the UC of students with low initial ability. The control class means that the class ability to understand the research class is higher than the testing class concept. Based on standard deviation data, the understanding of the mathematical concept of students with low motivation to learn in the testing class is more diverse than the research class because the SD of the testing class is higher than the research class.

Table 8. Data Statistics Tests Mathematical Problem Solving Low Initial Ability Students

\begin{tabular}{l|l|l|l|l}
\hline \multirow{2}{*}{ Gruop } & \multicolumn{4}{|l}{ Problem Solving } \\
\cline { 2 - 5 } & Xmin & Xmax & X & S \\
\hline Experiment & 12 & 23 & 17,8 & 4,087 \\
\hline Control & 0 & 20 & 8,778 & 7,067 \\
\hline
\end{tabular}

Based on the table 8 , the average GI ability of students with low motivation to learn of the research class is higher than the GI ability of students of low motivation to learn of the testing class means that the class of GI ability of the research class is higher than the GI of the testing class. Based on the standard deviation, the MGI of high initial ability students in the control class is more diverse than the experimental class because the high deviation value of the motivation high learn students in the control class is higher than the experimental class.

Table 9. Data Normality Test Concept Understanding Test and MGI Low Early Ability Students in Experiment and Control Class

\begin{tabular}{c|c|c|c|c}
\hline \multirow{2}{*}{ Value } & \multicolumn{4}{|c}{ Kemampuan Awal Rendah } \\
\cline { 2 - 5 } & \multicolumn{2}{|c}{ Experiment Class } & \multicolumn{2}{c}{ Control Class } \\
\cline { 2 - 5 } & $\begin{array}{c}\text { Undesrstand } \\
\text { Concept }\end{array}$ & $\begin{array}{c}\text { Problem } \\
\text { Solving }\end{array}$ & $\begin{array}{c}\text { Undesrstand } \\
\text { Concept }\end{array}$ & $\begin{array}{c}\text { Problem } \\
\text { Solving }\end{array}$ \\
\hline P-value & 0,200 & 0,200 & 0,200 & 0,180 \\
\hline Keterangan & Normal & Normal & Normal & Normal
\end{tabular}




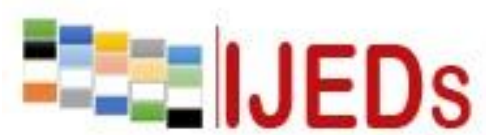

http://ijeds.ppj.unp.ac.id/index.php/IJEDS
International Journal of Educational Dynamics

Vol. 2 No. 1 (pp. 44-54) Desember 2019

p_ISSN 2655-4852

e_ISSN 2655-5093

On the Understanding Normality Test Concept students with low motivation to learn obtained the results for understanding the concept tests of normal research class and normal testing class. Because both classes have a P-value> 0.05 , it can be concluded that the data is normally distributed. So the Homogeneity test is performed with the test criteria if P-value> 0.05 then the data has a homogeneous variance. Based on the test results obtained by the value of P-value $=0.120$ so it can be concluded that the data has a homogeneous variance. For the Hypothesis Test carried out using the $t$ test. With the testing criteria if $\mathrm{P}$-value $>0.05$, accept $\mathrm{H}_{0}$. Based on testing the $\mathrm{P}$-value is obtained -0.101 so that the P-value> 0.05 then accept $\mathrm{H}_{0}$. This means that the concept of understanding students with low motivation to learn in the research class is not higher than understanding the concept of students with low motivation to learn.

To test the normality of problem solving students in the research class and the control class, the P-value of the experimental class is 0,200 and the P-value of the control class is 0.180 so that if both data are normal, it can be concluded that the data is normally distributed. Because the data is normally distributed, Homogeneity testing can then be carried out, with testing criteria if the P-value is> 0.05 , the data has a homogeneous variance. Based on the test results obtained $\mathrm{P}$-value $=0.076$ yag means $\mathrm{P}$ value $>0.05$ so it can be concluded that the data has a homogeneous variance. So to test the hypothesis is done using the $\mathrm{t}$ test. With the testing criteria Accept $\mathrm{H}_{0}$ if the value of $\mathrm{P}$-value> 0.05. Based on the results of the $\mathrm{t}$ test the value of $\mathrm{P}$-value is obtained $=$ 0.0115 so that Reject $\mathrm{H}_{0}$. This means that the GI tests of students with low motivation to learn in the research class are higher than the GI of students of low ability with control class.

\subsection{Interaction Test}

For the interaction test on the students' concept understanding test, it was carried out using the two-way ANAVA test.

\section{CONCLUSION}

- the influenceof cooperative learning model group investigation (GI) type and learning motivation in improving understanding and problem solving skills can be resolved as follows: 


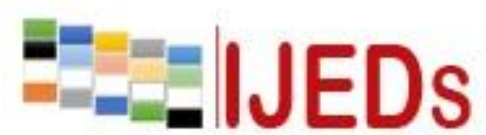

http://ijeds.ppj.unp.ac.id/index.php/IJEDS
International Journal of Educational Dynamics

Vol. 2 No. 1 (pp. 44-54) Desember 2019

p_ISSN 2655-4852

e_ISSN 2655-5093

- The ability to understand students' mathematical concepts is still not showing good results because of the results obtained by the control class the ability to understand the concepts better than the experimental class.

- MGI abilities of the research class students are better than the testing class

The influenceof cooperative learning model group investigation (GI) type and learning motivation can be used as an alternative for improvement in the learning process in schools, although in some implementations and the results there are still weaknesses and weaknesses so it still needs to be improved in its implementation.

So that students are better trained to build mathematical knowledge, it is better to use the cooperative learning model group investigation (GI) type and learning motivation in solving mathematics often used in the learning process.

For mathematics teachers and researchers, in order to better direct students to conduct group discussions, as well as propose problems that are appropriate to life become real

For subsequent researchers to be able to examine other variables that help the success of student learning, especially in the use of the influenceof cooperative learning model group investigation (GI) type and learning motivation in mathematics learning

\section{REFERENCES}

Daniela C. 2015. Problem Solving - Purpose And Means Of Learning Mathematics In School.

Arikunto, Suharsimi. 2005, Dasar - Dasar Evaluasi Pendidikan (Edisi Revisi). Jakarta : Bumi Aksara

Arsaytamby, V and Cut M. Z . 2014 . How A Realistic Mathematics Educational Approach Affect Students' Activites In Primary Schools?

Deporter, Bobby. 2004. Quantum Teaching. Bandung. KAIFA

De Lange. 1987. Mathematics Insight and Meaning. OW \& OC. Utreacht.

Fauzan, Ahmad. 2002. Applying RME in Teaching Geometry in Indonesian Primary School. Thesis University of Twente. Enschede: Print Partner IGIkampp. Press

Muliyardi. 2003. Srategi Belajar Mengajar. Jakarta: Bumi Aksara

Wijaya, Ariyadi. 2012 PMR suatu Alternatif Pendekatan Pembelajaran Matematika. Yogyakarta: Graha Ilmu 
International Journal of Educational Dynamics

$==-=\mid J E D S$

http://ijeds.ppj.unp.ac.id/index.php/IJEDS
Vol. 2 No. 1 (pp. 44-54) Desember 2019

p_ISSN 2655-4852

e_ISSN 2655-5093 